\title{
Artery of foramen rotundum: guilty or innocent?
}

\author{
Hyo Suk Nam, ${ }^{1}$ Joong Hyun Park, ${ }^{2}$ Sang Won Han ${ }^{2}$
}

${ }^{1}$ Department of Neurology, Yonsei University College of Medicine, Seoul, Republic of Korea

${ }^{2}$ Department of Neurology, Sanggye Paik Hospital, Inje University College of Medicine, Seoul, Republic of Korea

\section{Correspondence to} Professor Sang Won Han, swhan@paik.ac.kr
To cite: Nam HS, Park JH, Han SW. BMJ Case Reports Published online: [please include Day Month Year] doi:10.1136/bcr-2012008301

\section{DESCRIPTION}

Hemifacial spasm (HFS) is defined as involuntary, irregular clonic or tonic movement of muscles innervated by the ipsilateral seventh cranial nerve. ${ }^{1}$ While HFS is often attributed to a crosscompressive effect of an artery or arteries at the root exit zone of the facial nerve, there are other aetiologies that should be considered in the differential diagnosis.

A woman in her late 60 s visited a hospital due to a headache and involuntary muscular contractions of the left face. Symptoms started 3 years ago, initially affecting the left eyelids and then involving the ipsilateral lower facial muscles with gradually increased intensity and frequency of spasms during the last 6 months. Her medical history was negative except for hypertension. Physical examination did not reveal any abnormality other than HFS.

Brain MRI showed no associated neurovascular lesions. Cerebral angiography revealed an occlusion of the left cervical internal carotid artery (ICA). However, the artery of foramen rotundum anastomosed with the cavernous ICA and supplied the collateral flow (figure 1).

Hyperactive facial motor nucleus has been suggested as a possible mechanism of HFS associated with vascular migraine. Cluster headache is

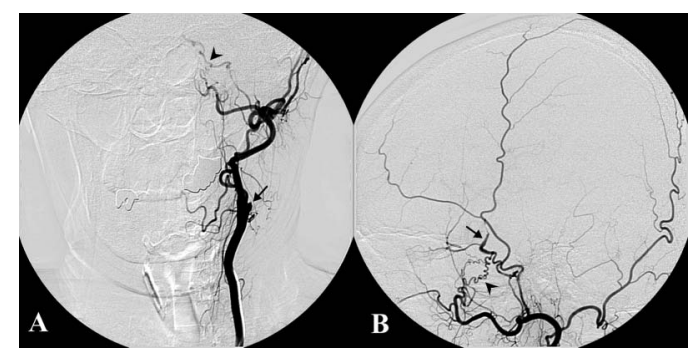

Figure 1 (A) Cerebral angiography showing the complete occlusion of the left internal carotid artery (ICA) at the cervical segment (arrow) and the artery of foramen rotundum (arrowhead). (B) The artery of foramen rotundum, which showing hypertrophy and tortuousness (arrowhead) anastomosing with the inferolateral trunk of the cavernous ICA (arrow) and supplying the collateral flow. postulated to be associated with an abnormal interaction between trigeminal afferents and cranial parasympathetic efferents. ${ }^{1}$ The trigeminal nerve in conjunction with the artery passes the foramen rotundum, and the excitability of facial motoneurons in HFS is modulated by afferent trigeminal inputs. ${ }^{2} 3$ The presence of collateral circulation via the artery of foramen rotundum may give an opportunity to have a benign neurological course but may exacerbate the HFS.

\section{Learning points}

While hemifacial spasm (HFS) is often attributed to a cross-compressive effect of an artery or arteries at the root exit zone of the facial nerve, there are other aetiologies that should be considered in the differential diagnosis.

- Hyperactive facial motor nucleus has been suggested as a possible mechanism of HFS associated with vascular migraine. The trigeminal nerve in conjunction with the artery passes the foramen rotundum, and the excitability of facial motoneurons in HFS is modulated by afferent trigeminal inputs. The presence of collateral circulation via the artery of foramen rotundum may exacerbate the HFS.

Competing interests None.

Patient consent Obtained.

Provenance and peer review Not commissioned; externally pee reviewed.

\section{REFERENCES}

1 Yaltho TC, Jankovic J. The many faces of hemifacial spasm: differential diagnosis of unilateral facial spasms. Mov Disord 2011;26:1582-92.

2 Ogawara K, Kuwabara S, Kamitsukasa I, et al. Trigeminal afferent input alters the excitability of facial motoneurons in hemifacial spasm. Neurology 2004;62:1749-52.

3 Pavesi G, Cattaneo L, Chierici E, et al. Trigemino-facial inhibitory reflexes in idiopathic hemifacial spasm. Mov Disord 2003;18:587-92. 
Copyright 2013 BMJ Publishing Group. All rights reserved. For permission to reuse any of this content visit http://group.bmj.com/group/rights-licensing/permissions.

BMJ Case Report Fellows may re-use this article for personal use and teaching without any further permission.

Become a Fellow of BMJ Case Reports today and you can:

- Submit as many cases as you like

- Enjoy fast sympathetic peer review and rapid publication of accepted articles

- Access all the published articles

- Re-use any of the published material for personal use and teaching without further permission

For information on Institutional Fellowships contact consortiasales@bmjgroup.com

Visit casereports.bmj.com for more articles like this and to become a Fellow 